\title{
7
}

\section{Shelley and the Revolution}

Shelley's life is known to us as yet only in fragments. Motives of delicacy and of family pride unite to keep the materials locked up, that, if published, would answer very important questions. Meanwhile the literature about the poet's fortunes and acts is large and unsatisfactory. To go among his biographers, who together fill a long library shelf, and to ask them for help in understanding him, is to enter a company of cultured and critical people who are all talking among themselves in low whispers, and, withal, quarreling. You may admire their enthusiasm, but they do not and cannot put your mind at rest. Furthermore, you are a little saddened to see how they hate one another. Each abuses at least one of his fellows, and all mystify. "If," says each, "if I were permitted to state my source of information, I could show that the real meaning of this or that event is quite other than the stupid and unworthy soul of my colleague, A. B., has held it to be." "I am informed by a person well qualified to judge, that," etc. Or, "Certain indications, which it were not prudent to explain at present, lead me to a grave suspicion just here, a suspicion, however, that I will not more clearly define, but only say that I have it. People of insight will follow me. I care for no others." Such is the tone of your true Shelley biographer. Exceptions to the rule there doubtless are. Two later biographers, Mr. W. M. Rossetti and Mr. J. A. Symonds, are tolerably plain spoken and satisfying, Mr. Symonds especially so. Yet

[Reprinted from FE, pp. 66-95.] 
they are limited by their material. They can not alter the fact that those who are best able to give us the truth about Shelley at first hand have not seen fit to do so, and that the tea-pot ocean of anecdote concerning our poet is yet ever liable to convulsive tempests of angry argument, whenever any new investigator sees fit to hunt up for us some scrap of news, and another investigator to abuse the first for doing so or for failing to add something else. Of this the moral is that we can not from Shelley's biography gain very much aid in understanding him as a man. Important it is to know about his life what we do; yet, with the rude sketch in black and white that is thus furnished, no one can be for a moment content. The reality and the coloring of our Shelley's character we must seek in his works. And in his works, too, we must find the inspiring ideas concerning which he was permitted to speak, and speak grandly to his fellowmen. With these ideas, and not with the outward embodiment of them in the wondrous and obscure happenings of the poet's life on the earth, our business must chiefly be whenever we speak in earnest and with genuine purpose about the poet Shelley.

Shelley must be viewed from as many sides as any mountain peak. I choose for the present to consider his place in the great mountain chain or range of his age, an age as full of great and of small things, of beautiful and of terrible things, as ever were Ural Mountains or Sierra, Andes or Himalaya. Shelley is a poet of the age of the Revolution. To this age we still belong. Do or say or think what we will, the Revolution-political, social, moral, religious, philosophical, poetical-is all about us in the air we breathe. Escape from it we cannot. For a full hundred years the spirit of the Revolution has forced every one to take some position in reference to itself. One may be conservative, or progressive, or reactionary; one may content himself with his newspaper, or spend all his days in studying the thought of his time in its best expressions; one may think for himself, or be able to buy his whole system at a bookstore for a few dollars, and stow it away half read on a shelf, as is just now the custom of very many who revere the name of Herbert Spencer; one may publish continually all that passes through his brain, and more, too; or one may preserve that enviable love of silent contemplation which is no less creative than are the great life-giving forces of springtime, when the little blades of grass fill their places and do not advertise their beauty-yet, do 
what one will, one is a unit in the great process of tremendous change which has gone on, now swift and now seemingly regressive, now terrifying and now quiet, but always intensely active, from the dawn of the French Revolution itself.

As a great man of the age of Revolution, and as a most characteristic man, one in whom the "passion for reforming the world" went side by side with the most original perception of the forces that move the world, Shelley is a form of life that we dare not leave out of sight in any effort we may make to survey the most important tendencies in modern thought and feeling. As undeveloped as he was many-sided and unfortunate, our poet is an image of the modern spirit itself-ardent, keen-sighted, aspiring, striving to be tolerant, yet often angry with misunderstanding; studious of the past, yet determined to create something new; anxious for practical reforms, yet conscious how weary the work of reform must be; above all, uncertain of the end, often despondent, not knowing what the fates may have decreed as a reward for all this strife, and incomplete, raw, or obscure, even in its most cherished and loftiest ideas. Of such a nature, I say, is Shelley, like the spirit of the age itself-not now, to be sure, strictly as poet, but as man, as moral teacher, as thinker. As poet, in the stricter sense, Shelley represents not so much the age as himself. For it pleases the World-Spirit at times to think highly original and peculiar thoughts; and these, embodied in living men, may make them incomparable with their fellows in some one respect, models and not things modeled after others; and such a distinct and lonely embodiment of ideas was Shelley the poet, who, as poet, might have been dropped down into any other age as well as into ours. Only as intellectual and as moral being may we claim him for our time, and find him one of the most striking representatives of the struggle with life problems which we ourselves carry on.

In studying, then, the relation of Shelley to the Revolution, one studies our poet, not in his most peculiar and most individual aspect, but without doubt, as I hold, in that aspect of his nature which means the most for the world at large. We always admire, to be sure, wonderful individuals. The "dæmoniac" power, whereby one soul conquers others with its fascination and leads them whithersoever it wills, is a power to which we delight to yield ourselves, with that love of the strongest which always guides us, even when we think ourselves most selfish. But the admiration for individuals 
is not the highest form of enthusiasm. The world is more than the men in it. The total of life is something more than the sum of the parts. The place of a man in the universe, in humanity, or in his age, is a more profitable subject for study than the remarkable skill, or beauty, or genius of this man himself. Shelley the moral man, the teacher, is higher in the scale of interest than Shelley the imaginative genius. And with Shelley the man we are now chiefly concerned.

When people speak of Shelley as preëminently a lyric poet, they commonly neglect to notice what profound consequences for his whole character, as a teacher of truth, are implied in this statement. Shelley is a lyric poet; but what is meant by the lyric power in poets? Is it not the power to view emotional experiences by themselves, to separate each of them from all others, to regard every grand moment of life as standing alone, as out of the chain of causes and effects, as a glorious or terrible accident? If this is the fact, and we shall find it true in Shelley's case, the peculiar fitness of our poet to embody and set forth the ideas of a period of revolution will at once be evident. When men break with past methods, the future seems to them a dark field full of strange adventures. What may come they know not; they are sure only of this: that the unexpected will happen, and nothing but the unexpected. The poet, who shall express their emotions, will then naturally be one to whom the world is less a finished system than a scene of grand actions, less a world of certainty than a world of magic. And such a poet will be lyric, rather than dramatic or epic. Let us trace some of the consequences of this general tendency in the case of our poet.

Born in the year $\mathrm{I792}^{2}$, just at the beginning of the most terrible days of the French Revolution, Percy Bysshe Shelley grew up in an atmosphere of unrest. That he was sensitive and misunderstood, inquiring and dissatisfied, we know. Many other boys in quieter times have been like him in these things. But his sensibility was fed with stimulating ideas that not all men hear of very early in life. Of these ideas the most commonplace, perhaps, were the ones that had to do with superstition and mysticism. The Revolution at the end of the last century began, as everybody knows, with not purely rationalistic tendencies. Rousseau was no rationalist, rather reactionary in these respects than otherwise. The whole revolutionary spirit rebelled not merely against the traditional 
social forms of Europe, not merely against the religious beliefs of ages, but also against the superficial philosophy of the eighteenth century itself. To explain the world by mere understanding was felt to be but a poor satisfaction for the many desires and hopes and fears and impulses that, in this time of restless activity, tinged men's notions of things. So, often in the early revolutionary period you find a vein of mysticism running side by side with the most stoutly radical tendencies. The greatest writers of the time have a mystical tinge in some part of their writings. Rousseau goes into raptures over the mysterious Being he feels everywhere in nature. Goethe, in his childhood, sets up an altar to worship the Eternal after his own fashion, in his early youth studies alchemy and speculates on the Trinity, in his early manhood writes the first part of Faust, in his old age the mystical choruses of the Epilogue. Schiller, less given to free contemplation of the world, is, by so much the more, a prey to reflective speculation on the hidden soul of things, and the Ghostseer and the philosophic lyrics testify to a sense of the mysterious, and an insight into the problematic side of life, which rationalism would wholly fail to comprehend. I need not speak at length of the German Romantic School proper, which sold its birthright to the succession of poetical empire for the poor boon of speculating on the realm beyond experience. England did not escape the contagion. To be sure, much of the nonsensical in this mystical reaction against rationalism was imported from Germany. "Monk" Lewis and many translators familiarized the public with what were little more than vulgar ghost stories, detestable even of their kind. But the genuine spirit, that was willing to see and express the mysterious in the strange destinies, emotions, and fears of a period of change, this natural and justifiable spirit of wonder, found in Coleridge's early poems, in Scott's healthy love of the marvelous, and, later on, in the early stages of the so-called Transcendental movement, a place on English, and, finally, on American ground. We must not despise even vagaries, in so far as they were honest vagaries, of this modern mysticism. Men felt, in the beginning of the Revolution, that the ground was insecure under their feet, that the future held great possibilities, that the world concealed the most weighty secrets. In all this, surely, they were right. To feel in view of the changes a superstitious terror, to picture in the realm of the possible all kinds of fantastic shapes, to interpret the worldsecrets in terms of human emotions-all this was doubtless wrong; 
yet certainly it was natural. Shelley was early a mystic. While yet a boy he read tales of wonder, and wrote them; he dabbled in such occult sciences as common acids and primitive electrical apparatus make possible, and believed he was treading on the verge of nature's deepest and most awful secrets; he conjured the devil with solemn earnestness, and hunted about in the dark for ghosts. Always a sceptic, he never ceased to be a mystic, and, if faith can be found among the followers of a revolution, Shelley held firmly to the end by this one faith, that, be this world what it may, it is at all events wonderful.

More important than his love of the mysterious was his love of freedom. This emotion Shelley breathed in the air about him, and found it intensified by his own heart. Few men have had the love of freedom in a purer form than he. Most men would like to be free themselves, and are willing that others should be what fortune makes them, so long as their lot be not all too hard. Shelley was absolutely universal, perfectly unselfish in his desire that men should be free. Freedom meant for him the same as the universal good of mankind. The slightest shadow of revenge he considered unworthy of the philanthropic soul; and so he would not deprive of liberty even the man who by wrong-doing had seemingly forfeited the right to it. In this one idea of liberty he bound up all his beliefs as to the rules of practical life. To study Shelley's theory of freedom is to study his poetry and prose, once for all, in its whole practical aspect. Most thoroughly an expression of the Revolution was our poet in this direction of his thought.

But yet another set of ideas went to the making of Shelley's world. Early he developed and enduringly he held by a sense of the worth of emotional experiences. In this sense of the significance of feeling Shelley is at one with the best spirits of the early revolutionary age. The rationalism of the first half of the eighteenth century had reduced everything to a mere affair of the understanding. The outburst of poetry which is contemporary with the outbreak of the political revolution is based on the recognition of the importance of feeling. Such a recognition the Storm and Stress poets forced on the German mind, and afterward the Lake school upon the English public, and again, years later, the French Romanticists on the thought of their own country. And one of the most dramatic histories that could be related of this century would be the history of the war of the intenser human feelings to gain and hold a place 
in esteem and influence beside the higher forms of human intellect. Our modern life is full of this conflict. Literature and daily experience furnish us numberless cases of the struggle, fought out on the grandest and on the humblest fields. An age full of change and of great thoughts is naturally an age of such tragedies.

Shelley never came to possess the sense of the worth of emotion; he always possessed it. In a sense in which few men have been uniformly and marvelously impressible, he was so. The power of vision never forsook him. We find him, to be sure, lamenting over his own weakness and poverty of experience:

O world! O life! O time!

On whose last steps I climb, Trembling at that where I had stood before, When will return the glory of your prime?

No more-oh, never more!

Out of the day and night

A joy has taken flight;

Fresh Spring, and Summer, and Winter hoar, Move my faint heart with grief-but with delight

No more, oh, never more!

But we know that all this divine sadness belongs to a world into whose lowest sphere we ascend but once in a long time. We know that the high visions the poet mourns are such as our eyes see not at all, while his monotony would be to us the most stirring emotional life. The poet moves us to sorrow; we lament with him, but these tears, this cry of anguish, these sobbing measures, we understand their true cause as little as if we were present at the funeral of a god, whom the other gods of high heaven were loudly mourning. What know we of climbing the last steps of life and time, or of the poet's joys that thus took wing? I speak of us as we are in general, single glimpses aside.

Thus far, then, we have noted certain tendencies in Shelley that seem directly expressive of the revolutionary spirit. Like all the general statements about poets, ours must have been found tedious and vague enough. We shall, in the sequel, do what we can to correct our fault by more special references to the poet's works themselves. Yet, before we go farther in this direction, a great question meets us face to face and demands answer, a question very general indeed, but very important. We have been speaking of the age and spirit of the Revolution. What do we mean by the 
revolutionary spirit? What by the Revolution itself? What is the true significance for human progress of the great movement in which Shelley is but a unit, in which, as we saw in the beginning, we ourselves must play our part, whether we will or not? I conceive it to be a necessary portion of the work planned at the outset that we should give some space to a brief summary of one view at least concerning this great problem.

To state, then, once more, our query: What is the revolutionary spirit? What is in general a revolution of human affairs and of human life? To answer the question neither too vaguely nor too hastily requires that we should revert for a little to first principles.

Our ideas of the world, of the society about us, of life, of ourselves, exhibit, when we look at them somewhat closely, this wonderful characteristic: namely, that we are ever forming them afresh, ever reconstructing them out of their elements, ever creating, as it were, the very products we are supposed most permanently to possess. When we speak the word Humanity, or the word Universe, or Life, or Time, or Being, we can do no real thinking with these words, unless, be it never so quickly and vaguely, we build up, put together, make syntheses of simpler ideas into the form of the great and complex idea suggested by the word used. Thoughts are not dead and finished mind-products that you can lay away on a shelf, so as to take them down entire, dry, and sound, when you want to use them. Thoughts are living, and each thought lives, in the most literal sense, but a moment. You must create your thought afresh whenever you want it. You create it, it flashes into active life for a moment, and then it is forever past. That thought cannot be recalled. You may make another like unto it. You may build ever afresh airy castles, and let time tear them down as soon as they are made. But retain the same thought more than an instant you cannot. Whatever treasures your mind possesses belong to it only in so far as you recreate them, reconquer them again and again, your whole life long. Activity, and ceaseless activity, is the price of the possession of even the humblest kind of knowledge. Give up acting, and all your past labors go for nothing. Even the most plodding soul is thus in so far original in its thoughts as that these result always from its own efforts exerted anew on every impulse. If one ceases entirely to be original, he ceases to think altogether. The essence of thinking is originality.

Our thoughts are thus always the products of momentary, im- 
mediately exerted activity. And so, of course, is our practical behavior in so far as it runs parallel to our ideas. We do this or that because Society approves of it, or because Law sanctions it, or because Humanity is benefited by it, or because the world appears to us such and such in nature and ordering, so that in it just this course of action is good. So, at least, we commonly account for our deliberate and most worthy acts. But to behave in this wise presupposes ideas of the world, of humanity, of law, of society-ideas complex and far-reaching which must, as shown, be formed anew whenever we have reason to form them.

So, then, in order to act at all well and deliberately in the greater affairs of life, men must be able easily and accurately to build up for themselves, just when they want them, clear notions of the great powers and facts that are concerned in human life. They must and do have well formed, if not quite finished, if often quite erroneous, ideas about the universe and about destiny in order to live well the humblest lives.

I lay stress on this great fact, because to understand it is necessary if you want to understand what is revolution. Men's ideas and practices are in so far changing and changing ever, as men active and men thoughtful are alike ever building up anew for themselves their world of ideas, of traditions, and of aims. The whole thoughtfabric of human life is there, because human beings will at each and every moment that it should be there. The most cruel wrong, the most painful superstition, the most worthless prejudice, is what it is, because mankind please at this instant to suffer it or to conform to it. The highest aims, the most enduring truths, the most comfortable persuasions, are what they are, because at each and every moment human consciousness creates them again out of chaos. The same mind-power that originated still sustains all that is great or contemptible, morally good or morally evil, in human life. Men's affairs, in so far as they are matters of thought at all, are solely what men make them. Only our sensations escape our control. Our thoughts are our own.

But there is another and a very different aspect to this same truth. Changing, renewing themselves, are all our thoughts and principles ever, but the new thoughts are commonly like the old thoughts, the new acts follow the track of their predecessors. If it is true that our lives at any moment are the products of that moment, it is none the less true that the product is formed with the least possible ef- 
fort, and that the least possible effort means conformity to previous acts. Hence, along with the fact of ceaseless activity in human thought and life goes the no less far-reaching fact of ceaseless economy of energy, of perennial laziness, in human thought and life. The world of thought for men is at each moment what men choose to find it; but let men alone, and they will choose to find or construct it at each moment just like the world of the previous moment. Without stimulus, without definite ends in view, men will indeed go on rebuilding their ideas every instant, but the rebuilding will not be a reformation, in the ordinary sense, but a building after the old models. This is what we mean by conservatism. The conservative spirit creates, indeed; it must do so. But it creates after the plan of its former creations. It originates, but by copying. All of us, however, left to ourselves, are conservatives. We need stimulus to make us otherwise. Wants that the old fashions by constructing our ideas will not satisfy, experiences that demand new forms of effort to bring them into harmony with older experiences, forces in the world beyond that call forth new answering strivings in our own hearts-these are the motives that lead us to be aggressive and revolutionary, to build our ideas after new fashions, to originate in a double sense, to will and purpose new things, to dwell as it were in a new world. Eating and drinking and sleeping are strictly conservative activities; they have to be performed ever afresh, but each new effort is like the former ones. Let us alone, entirely without disturbance, and conforming our lives to the rule of least waste of effort, we should inevitably do nothing but eat and drink and sleep. Disturbances arouse us, our fellowmen interfere with us, the struggle for life claims us, experience urges us with its scourge of many knotted problems, we cease to be purely conservative for a time, and rush on to some new stage of equilibrium. Our methods once formed and conformed to our circumstances, we act again in peace and with regularity, build our ideas according to our methods, and remain conservative till new impulses forbid us to continue longer in the same system and away we fly again in new revolution. Whence it follows that every revolutionary soul is seeking for nothing so much as an opportunity to become once more conservative, while every conservative differs not at all in his final aim from the upholder of revolution; for both desire to do with the least waste of effort what they must do as long as they live. Each seeks the easiest methods of forming his ideas and ordering his action. 
Only the thoughts of the revolutionary soul are more confused, and so harder to bring into clearness, than are those of the conservative; while the ideas of the conservative are less complex, less evolved, and so less lively and rebellious, than those of his brother. The innovator is higher in the scale of being, but he is imperfectly developed on his plane. The supporter of the old is a completer creature on the earth, but he is farther from Heaven. The restlessness of the revolutionary spirit is contagious, and reminds the conservative what he ought to be seeking-namely, something higher. The regularity of conservative methods that have grown to be a second nature is instructive, and admonishes the rebellious preacher of progress as to what he is seeking through all changesnamely, rest and stability.

A revolution, then, in life or in society, is, on its intellectual side, a great change in the methods whereby men form their notions of the things of life and the world-a change arising from this, that new material in experience or emotion refuses to be conquered by the old methods, or to conform itself to ideas of the old pattern. But as men are accustomed to conceive of new thing after old fashions so long as it is possible to do so, the old fashions of forming ideas will remain unchanged so long as there are not formed great masses of experience that rebel against the old methods. Then, at length, when the impossibility appears of thinking of the world and of life, of the government or of custom, of one's fellows or of nature, in the old way, then suddenly, with anguish and strife, the old methods are abondoned, the entire mode of forming ideas is changed, the fountains of the great deep are broken up, chaos seems imminent, and the struggle for new modes of living and thinking begins.

Of the great practical changes that go side by side with these theoretical changes, we need not speak at length. The alteration in ideas concerns us the more. And one or two especially noticeable things come just here in our way. The ideas, namely, and the ways of forming ideas, that were accounted useful and permanent before the revolution, become upon the approach of the revolution itself objects of unbounded contempt. A holy zeal to destroy takes possession of men. In the service of the Highest, they think, must they tear down and root out. Forgetting that the old methods were adequate for the old problems, that the old way of building ideas mastered the old material, and was in so far forth 
a true way, leading to relatively true ideas, men denounce the old age as an age of shams and errors, and speak of their present work as a work of regenerating or of creating the truth. Men do not bethink them that the old age, too, was creative, only in a conservative sense. The old ideas they call lies. For "lie" is a name quite often applied to an unserviceable truth, whether its uselessness arises from old age or from extreme novelty. Nor does the imperfection stop here. The revolution, like everything else in life, must have its own ways of forming ideas. Even provisionally, in all the confusion, notions about the world and about destiny must ever anew be created. The revolution throws away the old methods. Its system is not yet completed. It must furnish off-hand new methods. It resorts to high-sounding commonplaces, and wearies us with shallow truisms. The innovator talks of Liberty, of Nature, of Equality, as if with these barren ideas the whole complexity of life could be measured. Forgetting the negative character of the notions he recommends, forgetting that Nature means only the absence of voluntary interference, Liberty the absence of restraint, Equality the absence of definite moral relations, he calls upon all to solve the world-problem with him by repeating these abstractions, and he leaves us as unsatisfied and restless with it all as even his most unbounded revolutionary zeal could have desired to see us.

Such then is revolution, a conflict undertaken in the service of peace, a vast toil accepted in the interest of indolence; or, again, a destruction of numberless ideas and faiths, with the purpose of building up both knowledge and persuasion. No one understands the revolutionary spirit, I think, who does not see the deep-lying identity with it of the conservative spirit. As human nature is eternally active, the innovator is but the conservative with more perplexing facts before him, and the conservative only the upholder of revolution who has now, at length, no more worlds to conquer.

Thus, then, we have sought to give a clear, if very inadequate, idea of what revolution is. And, returning once more to our poet, we shall now understand better the meaning of the facts stated about him, and how he reflects in his own nature the spirit of a revolutionary time. We see how the unrest of the age finds expression in his mingling of the sceptical and mystical in his thought, how the gospel of the Revolution itself is embodied in his practical creed, and how the emotional strivings of the age receive in him a most wonderful representative. It remains for us to examine 
how these results of the Revolution, as embodied in the poet Shelley, are found to bear fruit in his works, and what lesson is thence to be drawn concerning the value of the tendencies of our time.

Shelley, the practical reformer, is the inspirer of such conceptions as the Prometheus, or as the Revolt of Islam. Shelley, the poet of great experiences, sparkles in a multitude of rare gems of lyric poetry. Shelley, not only as lyric poet, but as seer and mystic, produces such marvels as the Triumph of Life, the Epipsychidion, or the Adonais, and adorns the Prometheus itself. In all these three directions of activity Shelley is the child of the Revolution in so far forth as his aims, his problems, and his beliefs are framed by the revolutionary spirit.

Let us consider briefly the "Prometheus Unbound." A poem in the form of a drama, all of whose characters are supernatural beings, and withal abstractions, might be supposed lacking in human interest. It is not so, however. The keenest sense of the real problems of life pervades every line. The imagery is sometimes colossal, and sometimes subtle and delicate in the extreme, but never cold. A certain tendency to declamation one feels now and then in the first act; but, on the whole, a greater triumph over stubborn material cannot easily be found. The intensest sympathy with human sufferings and hopes could alone have made such triumph possible.

Prometheus is the representative of the soul of man. Personified as he is and given a real body and a real love, he loses something of his perfect character as representative, but gains in human interest. As we know him in Shelley he is a kind of divine man, strong, wise, good, deathless, sleepless. His fortitude in suffering claims our worship at first, his joy and dignity our sympathy at the end.

Forget for a moment, however, the personification. We are not enjoying the poem now, but thinking of its meaning. Let us see. through the allegory to the truth beneath. The soul of man then, the human consciousness viewed in its highest manifestations, is condemned by cruel wrong to suffer under oppressors. Who are these oppressors? Shelley evidently means this, that the wise and good and lofty in human nature is perpetually in chains because tradition and custom and government, the instruments of those who are malicious because ignorant and powerful, are ever striving to repress higher development and destroy higher wisdom. This is for the present the law, as it has been the law in the past, that the evil 
hates the good and is physically the stronger. Here, then, we have the first half of the revolutionary doctrine. The world, as it is, is bad, and must be changed.

The higher consciousness of man is content to endure this wrong, because it knows the end must come. In the fierce anguish of new or cruel oppression, it may, indeed, vent itself in cursing, not wishing other evil to happen to those who are evil than the fact of their baseness, but condemning them in its wrath to that, and leaving off all effort to save them. In calmer moments, however, it sees how much to be pitied are those who are evil. It withdraws its curses; but it has no thought of yielding. One great comfort it finds continually in the companionship of nature. All things mourn the oppression of man, as they will join in his rejoicings when he is free. To the higher consciousness all nature has a voice, is in league with the loftiest aims. But the soul of man has yet other comforts. The strivings of great thinkers to pierce the mystery of things, the outpourings of generosity and love, of poetic fervor and devotion to liberty-all these things are continual prophecies of the coming emancipation. Thus, in courage, and hope, and defiance, the unconquerable spirit lives on, and awaits the day of freedom.

But now, what and whence the deliverance? Can the apostle of the Revolution show us the means and the result of revolution? Evil has sprung up, and now rules the world. How is that evil to be destroyed? Is it not, as much as good, a necessary part of the universe, fixed beyond our power? If not, what are the laws whereby we can remove it? Prometheus can not destroy the evil himself; he is chained. He knows not how long the oppressor's rule will last; he knows only that it must some day end. I have heard of few stranger conceptions than this, emanating, as it does, from a reformer's mind-than this, I say, of the chained Prometheus, the hope and embodiment of all that is good, the divine genius of reform, unable to see a moment in advance the coming of his deliverer, only assured that a deliverer must some day come, and meanwhile inactive, unable by any word or sign to hasten the accomplishment of the deliverance, a slave of fate, a child of accident.

And yet to me welcome is day and night;

Whether one breaks the hoar-frost of the morn,

Or starry, dim, and slow, the other climbs

The leaden colored east; for then they lead 
The wingless, crawling Hours, one among whomAs some dark priest hales the reluctant victimShall drag thee, cruel king, to kiss the blood From these pale feet, which then might trample thee, If they disdained not such a prostrate slave.

What means this self-contradiction of the revolutionary spirit? Why is Prometheus, the representative of progress, a prey to accident, helpless? Is this merely the result of the fable, or the expression of Shelley's doctrine of life? Partly, of course, both; but mainly the result of the doctrine. Shelley need not have chosen Prometheus for his hero had he not wished it. He need not have bound himself with the chains of the old story had he not been willing. But, in fact, the world is to Shelley just this: a theatre of the sublimest accidents; a grand conflict of contrasts; a place where the triumph of good or of evil is a matter for joy or for lamentation, for enthusiasm or for horror, but never a definite end, to be reached or avoided by definite means. Shelley, the lyric poet, here appears in the strongest light. With the events and the experiences in the Prometheus we are held spellbound. Even their sequence, also, is sublime. But this sequence is as irrational, or super-rational, as it is sublime. Whether we hear about the dim and obscure Necessity, that some day the liberating hour should come, and the tyrant should fall, or whether we look merely at the grandeur of the event itself, the sudden outburst of the universe into a pæan of harmony and an ecstasy of sacred love-whatever we may do, we can but call the entire occurrence a mere happening, a wild chance. We rejoice that the chance has found such a poet to sing it. But we doubt whether this means anything at all for our poor, real world of practical life. Do reforms really come in this way? we say.

Angry we are at our own question immediately. Of course, this is an ideal picture of things. Of course, the poet leaves out of account the forces of reform, and sings the glorious fact of reform itself. His picture is true, as far as it goes. It pretends not to discourse of causes and effects. And yet we must feel that this is not enough to have said. There is a defect, not an artistic, but an ethical one, in this poem. The doctrine is, despite all, only the orthodox revolutionary doctrine again, the teaching that you need but strike off the chains and the reform is accomplished; that you need but love fervently enough, and hate is quelled; that, in a word, the 
world is a game-table, whereon a good throw of the dice must now forthwith be expected, because we have so long made bad throws.

That this was Shelley's doctrine appears, I think, from all his poetry, and from what we know of his life. His faith in the good, and in the triumph of the good, was sublime in its earnestness; but in its foundation it is much the same as the gambler's faith in luck, or as the ordinary stock optimism in which people always indulge when they wish to be considered especially clear-sighted. To say that in all things evil there is a soul of good; that the purpose of evil is simply to adorn and embellish good by contrast; that the deep desires of the human heart are certain to be realized-all this is supposed to be a sign of special profundity. Deeper, I think, would be the insight that were willing to recognize the problems of destiny as real, permanently real, and so forever insoluble problems; while itself only showed us what, in this checkered life, the truly and eternally good is, and bade us seek and increase that good as we are able. But all this shall be but an objection to Shelley's age, not to himself as the embodiment of it. To say that his optimism would have been shallow had it not been so deeply earnest, is to recognize the great truth about him, that he was undeveloped in his thought, but enviable in his ideas.

The revolutionary spirit as the gospel of the accidental was, I have said, especially fitted for Shelley's nature as a lyric poet. The effort he makes in Laon and Cythna (The Revolt of Islam) to set forth the doctrine of revolution at length and in order shows, I think, more than ever the truth of this observation. What a monstrous world of loveliness and horror, of glory and shame, is this into which the poet here introduces us. Yet this is the conception of the world which he learned from his time, adding only the touch of his own genius. One sees in this poem especially one great defect of the doctrine in question. If the belief in sublime accidents leads us to hope that men will suddenly be reformed, and the world suddenly turned from darkness to light, the same belief, making certain as it does the possibility of terrible accidents, leaves only too much room to dread that the good will give place to evil, the world return to its former errors, and life once more be shadowed. If progress be mainly negative and cataclysmic, what horrible reverses will not humanity have to endure throughout all time; the higher the development, the more terrible the disaster. 
It is strange to see how this doctrine, which one might suppose, after all, to be in Shelley the result of immaturity and of over-haste to teach his fellowmen, is in fact derived from his father after the spirit, in process of time his actual father-in-law, William Godwin, who had interpreted the doctrines of the Revolution to the young men of Britain in a book published first in 1793 , and known as Political Justice. Godwin's first period of literary activity, the one from which of course Shelley learned most, is distinguished by a vast confidence in the power of liberty to cure all ills. Shelley drank in eagerly the spirit of the doctrines long after the author had come to see reason to modify the latter, and he was certainly not wanting in effort to put ideas into practice. His expedition to Ireland for the sake of aiding Catholic emancipation and arousing the people is well known, and has, within a few years past, been investigated at length by Rossetti and McCarthy. Very fascinating is the preserved correspondence with Godwin at this time. Godwin had never met Shelley, knew him only by letter, but was not a little disturbed at witnessing the zeal of his young follower. He feared all manner of consequences, and used every effort to dissuade Shelley from continuing his work as an agitator. But Godwin's efforts would have been to little purpose had not the poet come to feel that, after all, his vocation was not in Ireland. Yet only by degrees did Shelley abandon his projects of immediate social reform. Probably he never gave up the idea of being a great reformer some day; and if he had lived, doubtless in the days that followed his name would have been heard in fields other than what are commonly known as poetical. A passage with which the young enthusiast closes a certain Declaration of Rights, a brief printed broadside composed during his Irish expedition, will serve to show us how his doctrines sounded when they are expressed, not in poetry, but in prose:

Man! thou whose rights are here declared, be no longer forgetful of the loftiness of thy destination. Think of thy rights, of those possessions which will give thee virtue and wisdom, by which thou mayest arrive at happiness and freedom. They are declared to thee by one who knows thy dignity, for every hour does his heart swell with honorable pride in the contemplation of what thou mayest attain-by one who is not forgetful of thy degeneracy, for every moment brings home to him the bitter conviction of what thou art. 
Evidently Shelley just here feels as much a hero as if he were Satan himself on the burning marl. He always had a proper and praiseworthy admiration for Satan.

But enough of criticism of the revolutionary gospel as Shelley preached it. We see here the mistake into which our century has ever been apt to fall, a mistake which just now we seek to correct by studying natural science and history-those two great teachers of law and moderation and doubt. The mistake lies in recognizing from one side only that eternal activity which we noticed at the outset-the life-power whereby men make anew at each instant their works of good and evil; in recognizing, I say, this one side of the truth, while forgetting the other side, to wit: the fact of what I have named the perennial laziness of human nature, which prevents men from forming their ideas at any moment differently from the way in which they formed them the moment before, unless both new method and new impulses are present to their consciousness. The Revolution said: Men make their lives such as they are; therefore, if men but willed it, the world would be happy; therefore, grant freedom of action, and nature will do the rest. But the truth is that men do will and must will to be as wretched as they are unless both knowledge and stimulus unite to bring them to a better mind; and even then the change will be slow, weary, full of anguish. We can never be sure that the life of benevolence and of nobility in aim is possible for the mass of the race until we see the result accomplished; and even in that case we have no reason to suppose that evil would be forever prevented, or the goal of progress attained.

The Revolution was at first optimistic. Shelley, as representing it, is in purpose at least an optimist. But the fault of optimism is its blindness, and its naive trust in the power of good intentions. In our time our duty is to correct this optimism by recognizing the ever-present fact of evil in the world. Not for a moment excusing evil nor yet daring to forget or overlook it, we must make up our minds to endless conflict while life lasts. We look forward to no haven of peace so long as we deal with life in its practical aspect. In contemplation, in knowledge, in worship, there is indeed peace; but these things belong not to active life, and to give ourselves up entirely to them is to be false to our duty to mankind. As men we must be in continual war. And even final victory for the right is never certain. 
But if the Revolution was imperfect, its spirit was noble; and we who inherit its problems dare not neglect to reverence its ambitions, its faith, and its pure intentions.

I turn to those other forms of Shelley's poetry wherein we may see embodied the intellectual and emotional tendencies of the Revolution. We have been looking at imperfections, not because we desired to pick flaws in Shelley, but because to note these things is profitable. Whatever belongs to our poet's genius we find above criticism. Only as the embodiment of the ideas of his time, or as immature and not wholly master of his material, does he seem to us now and then imperfect. But when we come to consider him as the poetic voice of the emotions of the century, or as seer to whom higher truth is often manifest, here we find him not learning from the age. His genius has full play. The time impedes him less and less.

To catch a fleeting experience in its marvelous perfection of emotional coloring, to crystalize it and make it eternal, to leave it a jewel in the world's treasure house for all time, that it may flash back in multitudinous rays (how well worn the poor figure is!) the light of all future life that falls upon it-this is the great work of the lyric poet. This Shelley has done, living as he did in the midst of a time of revived emotional life, and has done with a magic power at which we can only mutely marvel. Think of the "Indian Serenade," or of the "Lament," which has been already cited, or of the songs in the Prometheus, or of Beatrice's song in the last act of the Cenci:

False friend, wilt thou smile or weep

When my life is laid asleep?

Little cares for a smile or a tear

The clay-cold corpse upon the bier.

Farewell! Heigh-ho!

What is this whispers low?

There is a snake in thy smile, my dear,

And bitter poison within thy tear.

Sweet sleep! were death like to thee,

Or if thou couldst mortal be,

I would close these eyes of pain-

When to wake? Never again.

O, world! farewell!

Listen to the passing bell!

It says thou and I must part,

With a light and a heavy heart. 
Even the bitter and uncertain conflict to which the Revolution introduces us seems not too hard, if in its pauses we can hear at moments such strains of music as this, breathing as they do from and for hearts that, without all the bitter conflict, might be dead and joined to the things of earth alone.

But if already, as one who notes down experiences, Shelley is a marvel and a benefactor, as a seer of truth he has claims upon our regard even greater. The Revolution has meant for so many souls doubt, distress, hesitation in the choice of ideals, or even blank materialism of moral aims, that it is at once strange and refreshing to deal with a soul whose consciousness of the worth of ideal truth never falters, and that is withal so familiar a guest in the world of the ideals as to be quite unconscious that what itself tells us is at all extraordinary. Most mystics and idealists of any sort are a little proud of the fact, and like to recount to us with childish simplicity how they know secrets that they in no wise intend to reveal, how they deal with matters quite out of the common reach. Shelley has this in common with Swedenborg, that he is a very unmystical kind of mystic, and pretends to know a world of fact by no means so foreign in import to our own world. Shelley's mysticism is, however, unlike Swedenborg's, purely poetical, and hence perfectly safe, being judged altogether by the standards of emotional truth. He introduces us into the region of high contemplation, the region of all most secure from the disturbances of the world of practical life; and in this calm abode he entertains us with thought never dogmatic, infinitely plastic, and colored with all the many hues of his light-giving spirit. Here it is that Shelley appears at times as the man of a fervor rightly to be named religious. There is the same contempt of the finite, the same elevation above the world of sense, the same beatific vision, that marks the best moments of the saints of all ages. Adonais is the record of such experiences. The picture of that higher life which he for a moment attributes to the dead is not easily surpassable:

Peace! peace! he is not dead, he doth not sleepHe hath awakened from the dream of life'Tis we who, lost in stormy visions, keep With phantoms an unprofitable strife.

But as a seer, Shelley above all distinguishes himself in the character of a philosopher of love. In this realm so remote, and to most 
poets so inaccessible, of genuine unsentimental comprehension of the great passion, Shelley has obtained for himself the highest rank. And this is a subject of some importance for our present business, because the poets of the Revolution period have all been very wayward in their treatment of the higher affections; and, in the doubt and obscurity of mind attendant upon the revolutionary spirit, have run from the extreme of sentimental ecstasy to the extreme of scepticism in regard to the worth, the truth, and the enduring character of love. Shelley, in the Epipsychidion, and in many single passages, has dealt with the subject in a spirit of the happiest faith. Love is with him real, and of profound importance; but half the ordinary sentiment about it means nothing to him at all. Hardly a more profitable study in higher criticism could be mentioned than one that compared in detail, as Shelley himself has compared in general, Dante's Vita Nuova with the Epipsychidion; the philosophic love of the age of romance, given up as it is to deep selfquestionings, with the free, overflowing passion of this favored child of the age of Revolution, who had loved, as he said, an Antigone in some previous state of existence, and now could never rest in the precious toil of pursuing her shadow through all the world.

But, to sum up, we find in revolution the effort to accommodate the activity of thought and practical life to the ever new demands of emotion and experience. The Revolution of the past hundred years has expressed especially the need of the individual for fuller life, and for a better knowledge of his place in the universe. To use an expression from Novalis, many ways have the men of our day traveled; their end has been the same. To conquer the doubt of the time, and find themselves homes in the strange chaos of ideas with which the modern world seems filled, has been their common effort. Shelley, as a representative of the revolutionary spirit, has two chief things to teach us: that in the world of active life we are in no wise near to a solution of our problems. In the enthusiasm of the poet, which vented itself in dreams of an ideal society, dreams unlike the reality, and useless if they had been the reality, we see mirrored the incapacity of the modern spirit to lay the ghosts it has called up. Optimism is a resort as useless as it is unfounded. We are in the struggle of the Revolution still. We know not how it is to end. It would be no struggle if we did know. We know not that good must and will triumph. If we did know, 
why lay our vain hands on the ark and meddle with a predetermined fate? But, as such bold efforts as Shelley's teach us, we are unable to know. Progress is full of mishaps and accidents. Our duty is to watch and fight, ever on the lookout for foes, as a tiger in a jungle that the hunters are beating might wander, still brave and confident, but ever looking this way and that for the gleam of the bright spears. In active life the lesson Shelley teaches is, save for the example of his heroism, and devotion, and high purpose, mainly a negative one.

But as a child of the Revolution, Shelley gives example, too, of the intellectual and poetical results of the age of unrest; and here he is our guide altogether. As contemplation is ever better than action, as thought is higher than things, as ideals put to shame the efforts made to realize them, so does Shelley, in the world of ideas, stand far above the unrest of the age, a grand model. Send us, too, $\mathrm{O}$ Life, such power to endure and to see! If only at rare moments we are favored as he perpetually was, those moments will outweigh all the years of conflict, and uncertainty, and pain, and disappointment that lengthen out our lives, weary children as we are of an age filled with the woes of doubt and with toil in the dark. 